ENTREPRENEURSHIP AND SUSTAINABILITY ISSUES

ISSN 2345-0282 (online) http://jssidoi.org/jesi/

2021 Volume 9 Number 2 (December)

http://doi.org/10.9770/jesi.2021.9.2(23)

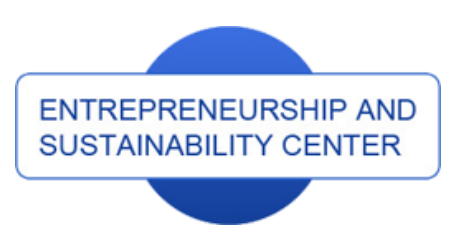

Publisher

http://jssidoi.org/esc/home
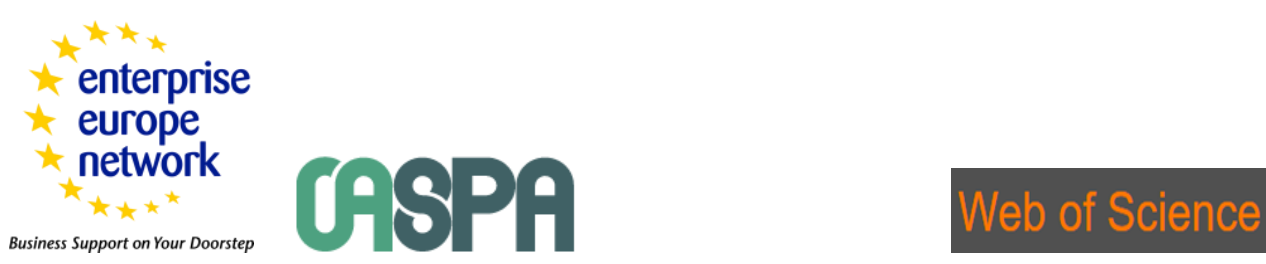

1) Clarivate

\title{
EVALUATION OF INDUSTRIAL ENTERPRISES' PERFORMANCE BY DIFFERENT GENERATIONS OF EMPLOYEES
}

\author{
Zdenka Gyurák Babel'ová ${ }^{1}$, Augustín Stareček ${ }^{2}$ \\ ${ }^{1,2}$ Slovak University of Technology in Bratislava, Faculty of Materials Science and Technology in Trnava, \\ Ulica Jána Bottu 2781/25, 91724 Trnava, Slovakia \\ E-mails: ${ }^{1}$ zdenka.babelova@stuba.sk, ${ }^{2}$ augustin.starecek@stuba.sk
}

Received 10 September 2021; accepted 2 November 2021; published 30 December 2021

\begin{abstract}
The performance of any industrial enterprise is of considerable importance for its long-term success and sustainable prosperity, but it cannot be considered as a certain and universal dimension. Business performance can be evaluated from different perspectives and with a focus on different aspects of performance. The main aim of the paper is to present the relationships between the perceived sustainable organizational and market performance of industrial enterprises and to compare the differences in the perception of selected performance indicators with respect to different generations of employees in industrial enterprises in Slovakia. To carry out the research, a research questionnaire was distributed to managers, specialists, and employees at administrative positions in industrial enterprises. In total, $\mathrm{n}=903$ respondents, employees of industrial enterprises operating in Slovakia were involved in the research. For the purposes of the research, two research questions and two research hypotheses were set. The research results proved a significant relationship between the perceived level of development of new products, services, or programs and profitability and also proved a significant relationship between perceived quality of products, services, or programs and profitability. The results of the research can be used to improve the evaluation of the sustainable organizational and market performance of the organizations and to improve human resource management with a focus on the coexistence of various generations of employees.
\end{abstract}

Keywords: generational groups; industrial enterprise; market performance; organizational performance; sustainability

Reference to this paper should be made as follows: Gyurák Babel'ová, Z., Stareček, A. 2021. Evaluation of industrial enterprises' performance by different generations of employees. Entrepreneurship and Sustainability Issues 9(2), 346-362. http://doi.org/10.9770/jesi.2021.9.2(23)

JEL Classifications: D24, E23, L15

Additional disciplines: sustainable management

\footnotetext{
* The paper is a part of project VEGA No. 1/0721/20 „Identification of priorities for sustainable human resources management with respect to disadvantaged employees in the context of Industry 4.0 “
} 


\section{ENTREPRENEURSHIP AND SUSTAINABILITY ISSUES}

ISSN 2345-0282 (online) http://jssidoi.org/jesi/

2021 Volume 9 Number 2 (December)

http://doi.org/10.9770/jesi.2021.9.2(23)

\section{Introduction and literature review}

Strategic orientation of organizational performance is crucial to gain significant benefits in the context of sustainability. Taking advantage of new opportunities for sustainable development can have a positive impact on organizational performance (Ameer and Khan, 2020). As stated in their studies (Bilan et al., 2020; Gavurova, Kocisova, Behun and Tarhanicova, 2018), sustainability can help promote and achieve excellent organizational performance and productivity in markets and environments. Sustainability represents developing an organization in which the right balance is created between economic, social and environmental goals (Lorincová et al., 2019; Székely and Knirsch, 2005; Jurík et al., 2020; Gyurák Babel’ová et al., 2020). In practice, sustainable performance is defined as a combination of its economic, social, and environmental dimensions. Such integration combines different factors from these three dimensions and suggests a synthetic approach to performance and integration of economic, social, and environmental organizational goals (Chardine-Baumann and Botta-Genoulaz, 2014). There are known examples of how to manage sustainability, linking sustainability performance, organizational competitiveness, and economic performance (Schaltegger and Wagner, 2017). Thus, the sustainable performance of a company represents not only ensuring economic growth and the good name of the company but also creating value for all stakeholders in the company while maintaining ethical and environmental rules. Sustainability in areas of the company's operations is an issue that has recently come to the fore (Al-Ali et al, 2020). Organizations can also contribute to building a sustainable society through active innovation of products and services that are not only economically attractive and environmentally green, but also contribute to meeting societal needs (Székely and Knirsch, 2005). Sustainable initiatives also contribute to the sustainable competitiveness of an organization (May and Stahl, 2017). The sustainable competitiveness of an organization is also related to innovation and market performance (Hussain et al., 2020). Product innovation can be a source of improving market performance which is crucial for the sustainable competitive advantage of the organization (Davcik et al., 2017). Organizations are looking for ways to improve performance impacting their competitiveness and doing it sustainably. Sustainable performance means that an organization performs efficiently and effectively when providing quality products and services. Human resources play an irreplaceable role in organizational performance. The research on human resource management and performance claims a significant positive relationship (Shah \& Khan, 2019). When evaluating the success of a company, terms such as performance, efficiency, and productivity are most often used, which overlap to a certain extent in their meaning (Veber, 2001). The most commonly used indicator of a company's performance and competitiveness is based on productivity (Falciola, Jansen and Rollo, 2020). Productivity is considered a degree of transformation (utilization or capitalizing) of resources in the form of useful outputs fulfilling the function of the organization (Veber, 2001). It is argued that productivity is the ability to create something regardless of its market value. Productivity simply assumes that what is produced will also manage market value (Karlöf and Lövingsson, 2006). However, higher productivity does not automatically mean increasing profitability (Huselid, 1995). The linkage between productivity and profitability can be considered in many ways. Profit change can be influenced by productivity change, operating efficiency change, or other effects (Grifell-Tatjé and Lovell, 1999).

Effectiveness in its most general meaning represents the efficiency of the use of resources and facilities in achieving goals (Stacho et al., 2019), and at the same time, it is a term that is understood both as a parameter expressing the ratio of input and output or as a relationship between economic performance and total cost of production (Veber, 2001). Performance is defined by the European Foundation for Quality Management (EFQM) as a measure of the results achieved by individuals, groups, organizations, and processes (EFQM, 2003). At the most general level, performance can be described as the essence of a company's existence. Performance expresses the company's ability to be successful and to further develop into the future (Fibírová and Šoljaková, 2005). The company's performance is the company's ability to achieve the desired effects or outputs, preferably in measurable units (Lesáková, 2004). However, an isolated performance assessment does not make sense. It is always necessary to assess the values in relation to a certain basis (values of the measured indicator in the past, values of the indicator for another company, comparison of actually achieved results with the plan or with the so-called ideal 


\section{ENTREPRENEURSHIP AND SUSTAINABILITY ISSUES}

ISSN 2345-0282 (online) http://jssidoi.org/jesi/ 2021 Volume 9 Number 2 (December) http://doi.org/10.9770/jesi.2021.9.2(23)

value of the indicator) (Majdúchová and Rybárová, 2019). When measuring performance, it is therefore very important to set performance measurement criteria as well as reference values or target values. The performance of an enterprise must be understood as a unique phenomenon, which is a summary of the benefits it brings to individual stakeholders. Enterprise performance management is important for an organization as also serves to gain a competitive advantage over its competitors (Rolstadås, 1998). Measuring and managing performance is the only way organizations can check that they are moving in the right direction and achieving their goals in terms of their predetermined goals (Ishaq, Awan and Razaq, 2014). Measuring and monitoring performance is also important for improving it (Browne et al., 1997).

Some authors state that the value of a company is determined by its performance (Neumaierová and Neumaier 2002; Suryani, et al., 2018). The fact that terms such as performance, efficiency, and effectiveness are interrelated or intertwined suggest two dimensions of performance, which are answers to the question of what should be done to move us towards a certain goal. The first of these "do the right things" indicates performance in terms of the choice of action we take. We usually refer to this dimension of performance as effectiveness. The second answer, "do the things right", shows performance in terms of the way we carry out the chosen activity. We usually refer to this dimension as efficiency (Marr, 2006; Wagner, 2009). In this meaning, efficiency and effectiveness are perceived as two dimensions of performance. Effectiveness is related to the utility because whether we are individuals or organizations, we strive for effectiveness in everything we do. By this, we mean that a utility will be created for someone in terms of the work and resources needed to create that utility. And at least we create usefulness for our own person, but through the organization, we usually strive to create benefit for someone else: customers, shareholders, members, or fellow citizens (Karlöf and Lövingsson, 2006). Performance can be examined at two levels, at the level of individuals and at the level of the company as a whole. Further performance analysis and apportionment is carried out in these two dimensions (Tomčíková, 2011). While productivity drivers of an enterprise are multiple and complex (Ballestar et al., 2020). Considering performance, however, we must always know about the performance of what is at stake. Thus, when analysing the performance of the organization, it is possible to focus on different aspects or areas of performance. Thus, the performance of the organization can be perceived from different points of view and measured at different levels. The most modern views on enterprise performance management are based on a very constructive idea that the ambition to interconnect and harmonize individual aspects of performance is the best way to achieve synergies that benefit the organization and all stakeholders around (Wagner, 2009).

The performance of an organization can be evaluated in different ways. It depends on the stakeholder who makes this assessment and each person that is in a certain relationship to the company may perceive its performance differently (Stýblo, 2008; Sulák and Vacík, 2005; Browne et al., 1997). The difference in the perception of the apportionment performance of the organization stems from the different perceptions of the stakeholders involved. The biggest challenge for the management of the organization is to maintain a balance between the expectations of the main stakeholders, which are its owners, customers, and employees. As some authors point out, employees are involved in transforming an organization's inputs into company outputs and creating value for the customer that it is willing to pay for it. Thus, they satisfy the primary interest group, which are the owners of the company (partners, shareholders), which has a clearly articulated interest in the existence and functionality of the company (Janišová and Křivánek, 2013). In addition to process performance, human performance plays a significant role in company performance (Marin-Garcia et al., 2011), whereas the performance of processes and people influence each other (Míkva, Vaňová and Szabó, 2017; Závadská and Závadský, 2014). Employees are, therefore, on the one hand, a very important interested party, which is one of the main stakeholders in the company's performance, and, on the other hand, they are a significant determinant of the enterprise's performance. However, there is very little or no attention paid to how the company's employees perceive its performance as one of the main interested parties in the company's performance. There is also a lack of attention paid to how employees perceive individual aspects, components, or dimensions of business performance. 


\section{ENTREPRENEURSHIP AND SUSTAINABILITY ISSUES}

ISSN 2345-0282 (online) http://jssidoi.org/jesi/ 2021 Volume 9 Number 2 (December) http://doi.org/10.9770/jesi.2021.9.2(23)

Generational changes and friction, which often occur at the dividing line between generations, are not new phenomena. Generational change and related problems have forever been part of human society. In the past, however, this process at the workplace has been limited to interactions between two generations of working age: one older generation leaving the workforce effectively and another younger generation entering it, even if at planned progress over the years (Sayers, 2007). At present, as in several European countries, several generations of employees work in the labour market. These generations are or have been influenced, among other factors, by the period in which they grew up and the various socio-economic influences that shaped their views and attitudes. The oldest generation on the labour market is the generation called Baby Boomers. Members of this generation were born in the years 1946-1960. Members of Baby Boomers are aware of their historical importance (Katz, 2017). They are characterized by the fact that they consider the work itself as a value, they also value financial security (Feeney, 2015) and expect to be rewarded at work for their experience (Gravett and Throckmorton, 2007). Predictions suggest that Baby boomers will be active, innovative, and productive for much longer than the generations before them (Coleman, Hladikova and Savelyeva, 2006). The importance of older people for business and entrepreneurship is increasing (Sudbury-Riley, Kohlbacher and Hofmeister, 2015). The aging of the population represents the deepest demographic change in history. Worldwide, life expectancy has increased by decades over five decades, and the severity of this demographic change is affecting economic growth as well as other areas such as labour markets and employment (UN, 2010). The next generation is called Generation X. Members of this generation were born in 1961-1980. Generation X is considered a loyal generation that has considerable influence and responsibility (Neal and Wellins, 2018). Generation X members do not accept traditional values, such as loyalty and collective duty, based on historical ideologies, but values that are close to the individual person and his or her experience (Češčut, 2010). Generation X is currently the one that supports society (Dancu, 2015). This generation has experienced extraordinary levels of technological changes in many areas (Sullivan, Brown and Bann, 2015). The next, younger generation is Generation Y born in 1981-1995. This generation has many opportunities for skills development and seeks constant feedback (Spiro, 2006). Compared to previous generations, Generation Y values a comfortable life (Murphy, Gibson and Greenwood, 2010). Members of this generation value practicality and approach everything individually, and this attitude is based on feelings and emotions (Oczachowska, 2020). Generation Y differs from previous generations and as such affects the dynamics of the organization in which it operates (Artar, 2019). They are characterized by flexibility greater than the flexibility of their predecessors and are open to change, ready to learn, and unwilling to long-term commitments (Karasek and Hysa, 2020). They are picky about choosing a job (Indriyana and Djastuti, 2019). They have a positive approach to work challenges and, together with a willingness to take responsibility, are closely linked to the need for lasting change and experimentation (Kuchárová-Mačkayová and Balažová, 2011). They prefer e-mail communication and communication via social networks (Kutlák, 2019). The last, youngest generation on the labour market is Generation Z, born in 1996-2009. This generation manifests itself as independent, but they are largely influenced by their friends and peers (Goh and Jie, 2019; Kamenidou et al., 2019). They prefer freedom and current consumption (Matraeva et al., 2019). It is appropriate to enable them to be surrounded by a creative environment where they can interact and collaborate (Mosca, Curtis and Savoth, 2019). Representatives of Generation $Z$ have the potential to introduce change and innovation in the business environment, thus improving economic growth and organizational efficiency (El-Gohary and Eid, 2013).

Generation values may vary from generation to generation. These different values of different generational groups can influence or control their consumer behaviour (Kaylene et al., 2010) or work preferences and responses to everyday life situations (Kupperschmidt, 2000). The coexistence and interaction of these generations bring benefits in the sense that members of each generation have certain strengths with regard to their living and working period, which enrich mutual cooperation. However, the interaction of these generations can bring various differences in attitudes or values that may hinder mutual cooperation. Given this possibility, it is important to know the differences in opinion and values of individual generations, which subsequently affect their attitudes and work or general behaviour and actions. 


\section{ENTREPRENEURSHIP AND SUSTAINABILITY ISSUES}

ISSN 2345-0282 (online) http://jssidoi.org/jesi/

2021 Volume 9 Number 2 (December)

http://doi.org/10.9770/jesi.2021.9.2(23)

\section{Methodology}

The next chapter of the presented paper is divided into four subchapters. There are defined the research problem and the aim of the research, the determination of research questions and the research hypothesis definition, a description of the data collection tool together with a description of the data collection, and the last part contains the characteristics of the research sample.

\section{Research problem and research aim}

The importance of innovation potential for organizations is emphasized by several works (Topolosky, 2000; Košturiak and Chal', 2008, Rr, 2020). Innovative practices have an impact on productivity (Katz, Kochan and Keefe, 1987). The innovations enable enterprises to perform more efficiently and to improve the productivity of the enterprise (Bruni and Verona, 2009; He, Guaita-Martínez and Botella-Carrubi, 2019).

The membership of the Slovak Republic in the European Union and the entering new organizations at Slovak market together with scientific and technical progress caused a competitive conflict between industrial enterprises (Samáková et al., 2017; Čambál, Cagaňová and Šujanová, 2012); Stachová et al., 2020; Gejdoš and Rentková, 2019; Kohnová, Papula and Salajová, 2019). Global changes, including the migration of the working population within the European Union, affect the results of industrial enterprises (Hysa, 2016; Grenčíková and Španková, 2016; Blahová and Pauliková, 2019). Another important factor influencing the composition of employees in industrial enterprises is the change of the demographic curve in the countries of the European Union (Mayhand, 2020) and thus also in the Slovak Republic (Spišáková et al., 2016). It follows from the above that various factors influence the structure of employees at the labor market in Slovakia in a positive and negative way. The inhomogeneity of the age structure means that industrial enterprises currently employ four generations of employees who are different in their personal, motivational, or value characteristics (Gravett and Throckmorton, 2007; Deal, 2007; McCrindle and Wolfinger, 2011). When formulating the research problem, we focused on how the company's employees, as one of the main interested parties in the performance of an enterprise, perceive the partial components of sustainable organizational and market performance. Previous researches (Dollinger, 1992; Powell, 1992) have shown that the perception of partial components of company performance can be considered a reliable indicator of company performance, as the perception of individual parts of organizational performance by employees reflects actual company performance (Delaney and Huselid, 1996).

The main aim of the research was to examine the perceived sustainable organizational and market performance of industrial enterprises with respect to different generations of employees.

\section{Research questions and research hypotheses}

The research problem is defined by determined research questions:

Research Question 1: How are selected indicators of organizational performance perceived by employees of industrial enterprises from different generations in comparison with the competitors for the last 3 years?

Research Question 2: How are selected indicators of market performance perceived by the employees of industrial enterprises from different generations in comparison with the competitors for the last 3 years?

Based on the theoretical basis and determined research questions, the following research hypotheses were defined: Research Hypothesis 1: There is a statistically significant relationship in the perception of employees in industrial enterprises between the factor "development of new products, services or programs" and the factor "profitability" within the perceived organizational and market performance. 


\section{ENTREPRENEURSHIP AND SUSTAINABILITY ISSUES}

ISSN 2345-0282 (online) http://jssidoi.org/jesi/

2021 Volume 9 Number 2 (December)

http://doi.org/10.9770/jesi.2021.9.2(23)

Research Hypothesis 2: There is a statistically significant relationship in the perception of employees in industrial enterprises between the factor "quality of products, services or programs" and the factor of "profitability" within the perceived organizational and market performance.

\section{Data collection and data collection tool}

The distribution of the collection tool took place during the months of September 2018 to January 2019. The questionnaire was distributed in person in paper form by physical distribution through several interviewers in industrial enterprises throughout the Slovak Republic. The unlikely quota selection of respondents was carried out by random distribution of the research questionnaire to ensure a normal distribution of all characteristics within the research sample. Participation in the research was voluntary and respondents were informed that collected data will be processed anonymously.

The research questionnaire contained 17 items (questions), which were homogeneously synthesized into logical groups according to the area on which the individual groups of questions focused. The first area contained items focused on the perceived organizational performance, and the second area contained items focused on perceived market performance. The remaining items were focused on socio-demographic characteristics. All homogeneous areas were internally consistent and statistically tested, where the values of the Crombach alpha coefficient reached the level: 0.85 and 0.82, which is sufficient for research purposes (Cortina, 1993), and therefore we can characterize the used questionnaire as reliable. The group of socio-demographic questions consists of the region of activity of the industrial enterprise, the size of the organization, gender, job position, and age of respondents. The possibilities of answering the questions were dichotomic, free, categorical, or interval. In addition to the primary scientific methods used in the creation of the entire research and the presented article, which include analysis, deduction, comparison, or generalization (Bednáriková, 2013; Ochrana, 2019), qualitative and quantitative methods were used for evaluating the collected data. For quantitative evaluation were used following programs: Microsoft Excel and IBM SPSS 22.0 (Statistical Package for the Social Sciences). For the data evaluation purposes, the authors of the paper used a tabular form together with histograms and pie charts, to clarify the individual results of the research.

\section{Description of the research sample}

The research sample consisted of employees from industrial enterprises operating in the Slovak Republic. In order to increase the representativeness of the sample, we decided to include in the research sample employees who work in industrial enterprises of various sizes and are members of all generational groups in the labour market. A total of $n=903$ respondents (employees of industrial enterprises) were involved in the research. The distribution of respondents by date of birth is shown in absolute numbers in Figure 1. 


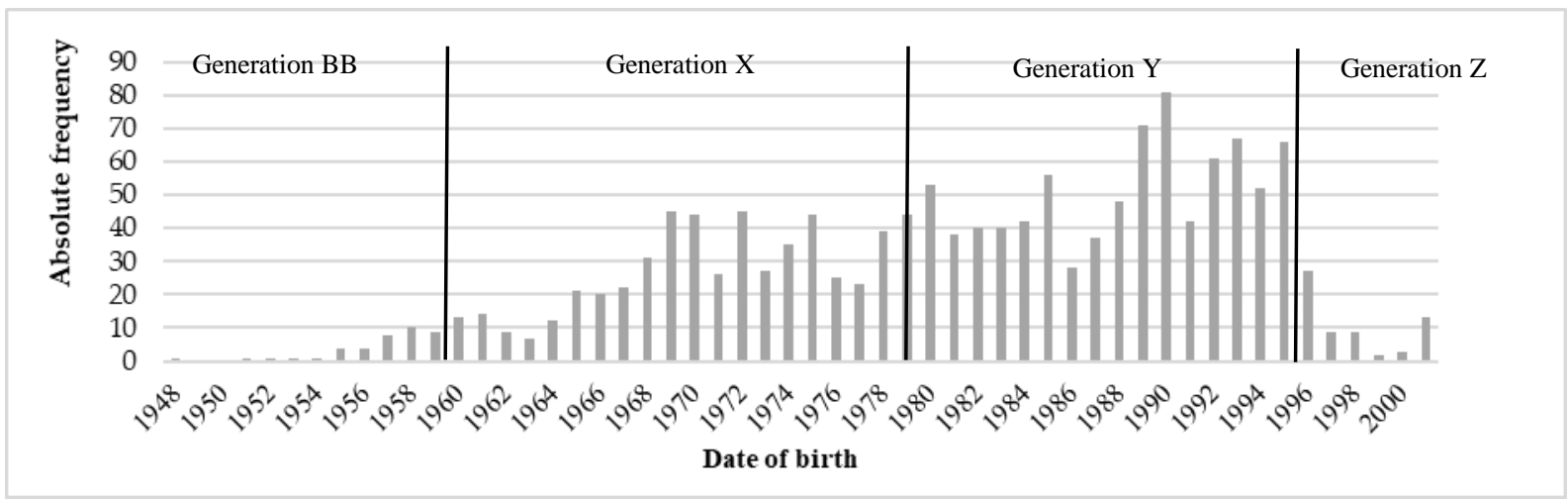

Figure 1. Distribution of respondents by date of birth

Source: own elaboration, 2021

As can be seen in Figure 1, the most numerous groups are respondents born in 1989-1990, the next most numerous groups are respondents born in 1992-1995, both belonging to generation Y. The respondents included in the research were employees of industrial enterprises at administrative positions, specialists, or managers.

The authors divided the respondents (employees of industrial enterprises) into individual generational groups (Baby Boomers born in 1946-1960; Generation X born in 1961-1980; Generation Y born in 1981-1995 and Generation $\mathrm{Z}$ born in 1996-2010). The absolute and relative number of respondents included in individual generation groups is shown in Table 1 .

Table 1. Distribution of respondents by generational groups

\begin{tabular}{|c|c|c|c|c|c|c|}
\hline Generations & Generation BB & Generation X & Generation Y & Generation Z & No answer & Total \\
\hline Absolute frequency & 24 & 348 & 500 & 24 & 7 & 903 \\
\hline Relative frequency [\%] & 2.66 & 38.54 & 55.37 & 2.66 & 0.77 & 100.00 \\
\hline
\end{tabular}

Table 1 shows the generational structure of respondents according to the classification of the individual generational group. The data in the table show that respondents belonging to the generation group Y (55.37\%) and X $(38.54 \%)$ have the largest representation. The ratio of generational groups participating in research also reflects the current representation of the labour population in the Slovak Republic in recent years. Due to the fact that some respondents did not answer the question concerning the year of birth, but answered the other questions of the questionnaire, they were included in the group without an answer $(0,77 \%)$. The following Table 2 shows the distribution of all respondents, participating in the research by job classification.

Table 2. Distribution of respondents by job classification

\begin{tabular}{|c|c|c|c|}
\hline Job classification & Administrative employees and specialists & Managerial staff & Total \\
\hline Absolute frequency & 631 & 272 & 903 \\
\hline Relative frequency [\%] & 69.88 & 30.12 & 100.00 \\
\hline \multicolumn{2}{|c|}{ Source: own elaboration, 2021 }
\end{tabular}

Table 2 shows that the largest representation among the analysed respondents had administrative employees and specialists $(69.88 \%)$. Respondents working at managing positions (team leaders, superiors, managers) had lower representation $(30.12 \%)$. 
ISSN 2345-0282 (online) http://jssidoi.org/jesi/

2021 Volume 9 Number 2 (December)

http://doi.org/10.9770/jesi.2021.9.2(23)

\section{Research results}

The following subchapter of the presented paper is divided into two parts, which are focused on the evaluation of the determined research questions and the evaluation of the defined research hypothesis.

Research Question 1: How are selected indicators of organizational performance perceived by employees of industrial enterprises from different generations in comparison with the competitors for the last 3 years?

The analysis of the first research question within the organizational performance of the company was focused on two factors, which are quality of products, services, or programs and development of new products, services, or programs. The results for analysed factors can be seen in Table 3 and Table 4, which contain the answers of employees of different generations in absolute and relative terms.

Table 3. Factor: quality of products, services, or programs

\begin{tabular}{|c|c|c|c|c|c|c|c|c|c|c|c|c|}
\hline \multirow{2}{*}{$\begin{array}{c}\text { Answer / } \\
\text { Generation }\end{array}$} & \multicolumn{2}{|c|}{ Generation BB } & \multicolumn{2}{|c|}{ Generation X } & \multicolumn{2}{|c|}{ Generation Y } & \multicolumn{2}{|c|}{ Generation $\mathrm{Z}$} & \multicolumn{2}{|c|}{ No answer } & \multicolumn{2}{|c|}{ Total } \\
\hline & $\begin{array}{c}\text { Relative } \\
\text { fr. }\end{array}$ & $\begin{array}{c}\text { Absolute } \\
\text { fr. }\end{array}$ & $\begin{array}{c}\text { Relative } \\
\text { fr. }\end{array}$ & $\begin{array}{c}\text { Absolute } \\
\text { fr. }\end{array}$ & $\begin{array}{c}\text { Relative } \\
\text { fr. }\end{array}$ & $\begin{array}{c}\text { Absolute } \\
\text { fr. }\end{array}$ & $\begin{array}{c}\text { Relative } \\
\text { fr. }\end{array}$ & $\begin{array}{c}\text { Absolute } \\
\text { fr. }\end{array}$ & $\begin{array}{c}\text { Relative } \\
\text { fr. }\end{array}$ & $\begin{array}{c}\text { Absolute } \\
\text { fr. }\end{array}$ & $\begin{array}{c}\text { Relative } \\
\text { fr. }\end{array}$ & $\begin{array}{c}\text { Absolute } \\
\text { fr. }\end{array}$ \\
\hline $\begin{array}{l}\text { Much } \\
\text { worse }\end{array}$ & 4.17 & 1 & 2.30 & 8 & 1.40 & 7 & 0.00 & 0 & 14.29 & 1 & 1.88 & \multirow{2}{*}{150} \\
\hline Worse & 12.50 & 3 & 15.52 & 54 & 14.40 & 72 & 0.00 & 0 & 57.14 & 4 & 14.73 & \\
\hline Better & 75.00 & 18 & 65.23 & 227 & 65.80 & 329 & 83.33 & 20 & 0.00 & 0 & 65.78 & \multirow[b]{2}{*}{744} \\
\hline $\begin{array}{l}\text { Much } \\
\text { better }\end{array}$ & 8.33 & 2 & 16.09 & 56 & 17.20 & 86 & 16.67 & 4 & 28.57 & 2 & 16.61 & \\
\hline No answer & 0.00 & 0 & 0.86 & 3 & 1.20 & 6 & 0.00 & 0 & 0.00 & 0 & 1.00 & 9 \\
\hline Total & 100.00 & 24 & 100.00 & 348 & 100.00 & 500 & 100.00 & 24 & 100.00 & 7 & 100.00 & 903 \\
\hline
\end{tabular}

Table 3 shows that employees generally perceive the organizational performance factor quality of products, services, or programs better and much better (744) and only (150) respondents perceive this factor as much worse and worse compared to their competitors. Partial analysis showed that Generation X rated the factor as much worse and worse $(72.82 \%)$. On the contrary, Generation $\mathrm{Z}$ rates it $(100 \%)$ as much better and better. For Generation Z, there is no indication of a negative evaluation of products, services, or programs quality compared to the competitors. Different perceptions of product quality by different generations of employees may be related to the different duration of their memory trace. Older employees have a longer memory trace and remember that in the past, products were made so that they would not spoil and last as long as possible. Subsequently, the products were manufactured so that they could be easily repaired or disassembled. At present, products are perceived very consumedly, which means that it is common for them to go wrong and have to replace the whole product with a new model. However, such an approach to product quality negatively affects sustainability and sustainable development. Another considered factor of organizational performance was the development of new products, services, or programs, the results for this factor can be seen in Table 4, which is shown below. 
Table 4. Factor: development of new products, services, or programs

\begin{tabular}{|c|c|c|c|c|c|c|c|c|c|c|c|c|}
\hline \multirow{2}{*}{$\begin{array}{c}\text { Answer / } \\
\text { Generation }\end{array}$} & \multicolumn{2}{|c|}{ Generation BB } & \multicolumn{2}{|c|}{ Generation $\mathrm{X}$} & \multicolumn{2}{|c|}{ Generation $\mathbf{Y}$} & \multicolumn{2}{|c|}{ Generation $\mathbf{Z}$} & \multicolumn{2}{|c|}{ No answer } & \multicolumn{2}{|c|}{ Total } \\
\hline & $\begin{array}{c}\begin{array}{c}\text { Relative } \\
\text { fr. }\end{array} \\
\end{array}$ & \begin{tabular}{|c|}
$\begin{array}{c}\text { Absolute } \\
\text { fr. }\end{array}$ \\
\end{tabular} & $\begin{array}{c}\begin{array}{c}\text { Relative } \\
\text { fr. }\end{array} \\
\end{array}$ & \begin{tabular}{|c|}
$\begin{array}{c}\text { Absolute } \\
\text { fr. }\end{array}$ \\
\end{tabular} & $\begin{array}{c}\begin{array}{c}\text { Relative } \\
\text { fr. }\end{array} \\
\end{array}$ & \begin{tabular}{|c|}
$\begin{array}{c}\text { Absolute } \\
\text { fr. }\end{array}$ \\
\end{tabular} & $\begin{array}{c}\begin{array}{c}\text { Relative } \\
\text { fr. }\end{array} \\
\end{array}$ & \begin{tabular}{|c|}
$\begin{array}{c}\text { Absolute } \\
\text { fr. }\end{array}$ \\
\end{tabular} & $\begin{array}{c}\begin{array}{c}\text { Relative } \\
\text { fr. }\end{array} \\
\end{array}$ & \begin{tabular}{|c|}
$\begin{array}{c}\text { Absolute } \\
\text { fr. }\end{array}$ \\
\end{tabular} & $\begin{array}{c}\begin{array}{c}\text { Relative } \\
\text { fr. }\end{array} \\
\end{array}$ & $\begin{array}{c}\begin{array}{c}\text { Absolute } \\
\text { fr. }\end{array} \\
\end{array}$ \\
\hline $\begin{array}{l}\text { Much } \\
\text { worse }\end{array}$ & 0.00 & 0 & 3.74 & 13 & 2.40 & 12 & 4.17 & 1 & 28.57 & 2 & 3.10 & \multirow{2}{*}{235} \\
\hline Worse & 29.17 & 7 & 21.26 & 74 & 23.80 & 119 & 20.83 & 5 & 28.57 & 2 & 22.92 & \\
\hline Better & 54.17 & 13 & 56.90 & 198 & 54.80 & 274 & 45.83 & 11 & 28.57 & 2 & 55.15 & \multirow[b]{2}{*}{651} \\
\hline $\begin{array}{l}\text { Much } \\
\text { better }\end{array}$ & 16.67 & 4 & 17.24 & 60 & 17.60 & 88 & 29.17 & 7 & 14.29 & 1 & 17.72 & \\
\hline No answer & 0.00 & 0 & 0.86 & 3 & 1.40 & 7 & 0.00 & 0 & 0.00 & 0 & 1.11 & 10 \\
\hline Total & 100.00 & 24 & 100.00 & 348 & 100.00 & 500 & 100.00 & 24 & 100.00 & 7 & 100.00 & 903 \\
\hline
\end{tabular}

Table 4 shows that respondents, employees of industrial enterprises from different generations, mostly evaluated the development of new products and services as much better and better (658). Compared to the previous factor, however, there are more respondents who rate the development of new products, services, or programs as much worse or worse (235). The partial analysis shows that the Baby Boomers generation evaluates the worst (29.17\%) development of new products, services, or programs. The development of new products, services, and programs is evaluated as the best by Generation $\mathrm{Z}(75 \%)$. The importance of the innovation potential of companies is also confirmed by the latest experience with the operation of companies under specific regimes. Based on the analysis carried out by IPA Slovakia, companies affected by restrictions related to the societal threat of the COVID-19 virus can be divided into three groups. For companies that have a decline in orders - especially the automotive industry (Debnár, 2020). Also, according to a press release from Euler Hermes, a world leader in trade receivables insurance and a recognized risk assessment specialist, the automotive industry, together with transport, is the most vulnerable sector of the Covid-19 crisis (Euler, 2020). The second group consists of companies that have neither improved nor deteriorated in terms of the volume of orders and companies that have increased the volume of orders and are "in backlog". These are companies mainly in the food, hygiene, chemical, and pharmaceutical industries (Debnár, 2020). This third group also includes companies that have been able to quickly adapt and adjust their product portfolios to current market needs. From this point of view, the ability to come up with a new product as a factor of market performance is proving to be crucial, especially in whole society crises.

Research Question 2: How are selected indicators of market performance perceived by the employees of industrial enterprises from different generations in comparison with the competitors for the last 3 years?

The analysis of the second research question is focused on two factors of market performance, which are an increase in sales and profitability. The evaluation of considered factors can be seen in Table 5 and Table 6 , which contain the responses of employees from different generations in absolute and relative terms. 
ENTREPRENEURSHIP AND SUSTAINABILITY ISSUES

ISSN 2345-0282 (online) http://jssidoi.org/jesi/

2021 Volume 9 Number 2 (December)

http://doi.org/10.9770/jesi.2021.9.2(23)

Table 5. Factor: Increase in sales

\begin{tabular}{|c|c|c|c|c|c|c|c|c|c|c|c|c|}
\hline \multirow{2}{*}{$\begin{array}{c}\text { Answer / } \\
\text { Generation }\end{array}$} & \multicolumn{2}{|c|}{ Generation BB } & \multicolumn{2}{|c|}{ Generation $\mathrm{X}$} & \multicolumn{2}{|c|}{ Generation Y } & \multicolumn{2}{|c|}{ Generation $Z$} & \multicolumn{2}{|c|}{ No answer } & \multicolumn{2}{|c|}{ Total } \\
\hline & $\begin{array}{c}\text { Relative } \\
\text { fr. }\end{array}$ & $\begin{array}{c}\text { Absolute } \\
\text { fr. }\end{array}$ & $\begin{array}{c}\text { Relative } \\
\text { fr. }\end{array}$ & $\begin{array}{c}\text { Absolute } \\
\text { fr. }\end{array}$ & $\begin{array}{c}\text { Relative } \\
\text { fr. }\end{array}$ & $\begin{array}{c}\text { Absolute } \\
\text { fr. }\end{array}$ & $\begin{array}{c}\text { Relative } \\
\text { fr. }\end{array}$ & $\begin{array}{c}\text { Absolute } \\
\text { fr. }\end{array}$ & $\begin{array}{c}\text { Relative } \\
\text { fr. }\end{array}$ & $\begin{array}{c}\text { Absolute } \\
\text { fr. }\end{array}$ & $\begin{array}{c}\text { Relative } \\
\text { fr. }\end{array}$ & $\begin{array}{c}\text { Absolute } \\
\text { fr. }\end{array}$ \\
\hline $\begin{array}{l}\text { Much } \\
\text { worse }\end{array}$ & 0.00 & 0 & 2.30 & 8 & 1.20 & 6 & 0.00 & 0 & 0.00 & 0 & 1.55 & \multirow{2}{*}{213} \\
\hline Worse & 20.83 & 5 & 25.29 & 88 & 19.80 & 99 & 12.50 & 3 & 57.14 & 4 & 22.04 & \\
\hline Better & 62.50 & 15 & 54.31 & 189 & 58.20 & 291 & 58.33 & 14 & 28.57 & 2 & 56.59 & \multirow[b]{2}{*}{677} \\
\hline $\begin{array}{l}\text { Much } \\
\text { better }\end{array}$ & 12.50 & 3 & 16.67 & 58 & 19.40 & 97 & 29.17 & 7 & 14.29 & 1 & 18.38 & \\
\hline No answer & 4.17 & 1 & 1.44 & 5 & 1.40 & 7 & 0.00 & 0 & 0.00 & 0 & 1.44 & 13 \\
\hline Total & 100.00 & 24 & 100.00 & 348 & 100.00 & 500 & 100.00 & 24 & 100.00 & 7 & 100.00 & 903 \\
\hline
\end{tabular}

Table 5 shows that the respondent - employees of industrial enterprises from different generations perceive the factor increase in sales overall much better and better (677), while up to 388 respondents rated the factor as much worse and worse (213), compared to competitors. A partial analysis of the results by generation showed that employees of the Generation X rated the increase in sales much worse and worse $(27.59 \%)$. On the other hand, Generation $\mathrm{Z}$ evaluates sales growth much better and better $(87.5 \%)$. The second analyzed factor was market performance profitability, the result for this factor can be seen in Table 6 below.

Table 6. Factor: Profitability

\begin{tabular}{|c|c|c|c|c|c|c|c|c|c|c|c|c|}
\hline \multirow{2}{*}{$\begin{array}{c}\text { Answer / } \\
\text { Generation }\end{array}$} & \multicolumn{2}{|c|}{ Generation BB } & \multicolumn{2}{|c|}{ Generation X } & \multicolumn{2}{|c|}{ Generation Y } & \multicolumn{2}{|c|}{ Generation $\mathrm{Z}$} & \multicolumn{2}{|c|}{ No answer } & \multicolumn{2}{|c|}{ Total } \\
\hline & $\begin{array}{c}\text { Relative } \\
\text { fr. }\end{array}$ & $\begin{array}{c}\text { Absolute } \\
\text { fr. }\end{array}$ & $\begin{array}{c}\text { Relative } \\
\text { fr. }\end{array}$ & $\begin{array}{c}\text { Absolute } \\
\text { fr. }\end{array}$ & $\begin{array}{c}\text { Relative } \\
\text { fr. }\end{array}$ & $\begin{array}{c}\text { Absolute } \\
\text { fr. }\end{array}$ & $\begin{array}{c}\text { Relative } \\
\text { fr. }\end{array}$ & $\begin{array}{c}\text { Absolute } \\
\text { fr. }\end{array}$ & $\begin{array}{c}\text { Relative } \\
\text { fr. }\end{array}$ & $\begin{array}{c}\text { Absolute } \\
\text { fr. }\end{array}$ & $\begin{array}{c}\text { Relative } \\
\text { fr. }\end{array}$ & $\begin{array}{c}\text { Absolute } \\
\text { fr. }\end{array}$ \\
\hline $\begin{array}{l}\text { Much } \\
\text { worse }\end{array}$ & 0.00 & 0 & 4.02 & 14 & 2.20 & 11 & 0.00 & 0 & 0.00 & 0 & 2.77 & \multirow{2}{*}{229} \\
\hline Worse & 25.00 & 6 & 22.99 & 80 & 22.00 & 110 & 16.67 & 4 & 57.14 & 4 & 22.59 & \\
\hline Better & 62.50 & 15 & 51.72 & 180 & 49.60 & 248 & 62.50 & 15 & 28.57 & 2 & 50.94 & \multirow[b]{2}{*}{660} \\
\hline $\begin{array}{l}\text { Much } \\
\text { better }\end{array}$ & 8.33 & 2 & 20.11 & 70 & 24.40 & 122 & 20.83 & 5 & 14.29 & 1 & 22.15 & \\
\hline No answer & 4.17 & 1 & 1.15 & 4 & 1.80 & 9 & 0.00 & 0 & 0.00 & 0 & 1.55 & 14 \\
\hline Total & 100.00 & 24 & 100.00 & 348 & 100.00 & 500 & 100.00 & 24 & 100.00 & 7 & 100.00 & 903 \\
\hline
\end{tabular}

Table 6 contains the results for the analysed market performance factor profitability. Overall, respondents (employees of industrial enterprises) rated profitability as much better and better (660) and the results are almost similar to the previous factor increase in sales. Respondents from Generation X perceive profitability as much worse and worse $(27.01 \%)$. Generation $\mathrm{Z}$ employees evaluated profitability mostly as much better and better $(83.33 \%)$.

The results of the presented research showed that there is a difference in the perception of individual components of organizational and market performance between different generations of employees. While the younger generations evaluate these indicators as better, the oldest generation is more careful in the evaluation and attributes a worse evaluation of the analysed factors.

Research Hypothesis 1: There is a statistically significant relationship in the perception of employees in industrial enterprises between the factor "development of new products, services or programs" and the factor "profitability" within the perceived organizational and market performance. 


\section{ENTREPRENEURSHIP AND SUSTAINABILITY ISSUES}

ISSN 2345-0282 (online) http://jssidoi.org/jesi/

2021 Volume 9 Number 2 (December)

http://doi.org/10.9770/jesi.2021.9.2(23)

The result of Pearson's correlation test showed that there is a statistically significant relationship in the perception of employees in industrial enterprises from different generations between the factor new product, service, or program development and the factor of profitability. The mentioned variable correlates at the level of sig $=0.05$ with the value of the Pearson correlation coefficient $r=0.509$. The value of significance reached the required level (sig <0.05), therefore we do not refute the hypothesis and we can confirm that there is a strong correlation between the tested variables.

Research Hypothesis 2: There is a statistically significant relationship in the perception of employees in industrial enterprises between the factor "quality of products, services or programs" and the factor of "profitability" within the perceived organizational and market performance.

The result of Pearson's correlation test showed that there is a statistically significant relationship in the perception of employees in industrial enterprises from different generations between the factor quality of products, services, or programs and the factor of profitability. The mentioned variable correlates at the level of sig $=0.05$ with the value of the Pearson correlation coefficient $r=0.372$. The value of significance reached the required level (sig $<0.05$ ), therefore we do not refute the above hypothesis and we can confirm that there is a medium correlation between the tested variables.

\section{Conclusions}

The involvement of stakeholders in the creation of strategies improves the organization's ability to create its own future by re-evaluating the basic assumptions and values on which the organization's strategies are based (Stead \& Stead, 2009). At present, various generations of employees meet at the workplace at the same time. These generations differ in their attitudes, values, and views on the performance of the organization. In order for management to use their contribution to creating the future of the organization, it is important to know their views on organizational performance. The research revealed the need to examine the perception and attitudes of employees with respect to various generations. In future research, we would focus on specific areas of sustainable organizational and market performance with an emphasis on sustainability and sustainable competitive advantage creation.

We have not yet experienced the limitations and limits that the current time brings, and the management of industrial enterprises has no experience with them at all. Many areas are not managed centrally, so there is expected proactivity and invention of the management of industrial enterprises (Debnár, 2020). Current time and its limitations bring many challenges that they have to face for a long time. That is why it is important for the management that the organization have the necessary potential in addition to achieving results. Innovation potential, the ability to adapt to market conditions and current requirements and requirements on demands are proving to be key in crises. For this reason, the ability to come up with a new product as a factor in market performance is proving to be crucial, especially in critical social situations. This fact was also proved by the testing defined research hypotheses, where is a statistically significant relationship between perceived profitability (market performance) and the development of new products and services (organizational performance). Based on the perception of employees of industrial enterprises, introducing innovations has a greater impact on consumer behavior and increasing profitability as a factor of market performance than maintaining the quality of products and services provided.

When managing performance, the management of enterprise focuses mainly on rather quantifiable performance indicators: economic, financial indicators, achieved profit, and whether there is labor productivity, which, however, often do not reflect the actual performance of the organization. These indicators reflect previous periods and cannot be used to predict the ability of an enterprise to grow or survive in new or crises. However, from the point of view of objective assessment of the enterprise performance, it is important that the owners or managers of 


\section{ENTREPRENEURSHIP AND SUSTAINABILITY ISSUES}

ISSN 2345-0282 (online) http://jssidoi.org/jesi/ 2021 Volume 9 Number 2 (December)

http://doi.org/10.9770/jesi.2021.9.2(23)

the enterprise focus not only on financial, often considered as objective indicators of the business success, but also take into account the opinion on performance from the perspective of individual stakeholders. Although the importance of employees in creating value and contributing to business performance is often emphasized, employees are often overlooked as one of the major interested parties that represents one of the main stakeholders in business performance. The employees' perception of enterprise performance is an important indicator that indicates not only the current state or success of the enterprise but in the context of sustainable development has significant predictive importance in terms of using the human potential to ensure sustainable prosperity

\section{References}

Al-Ali, N. M.Y.M., Gorgenyi-Hegyes, E. \& Fekete-Farkas, M. (2020). Perceived corporate sustainability practices and performance of small and medium enterprises (SMEs) in Qatar. Polish Journal of Management Studies, 22(1), 26-42. https://doi.org/10.17512/pjms.2020.22.1.02

Ameer, F. \& Khan, N. R. (2020). Manager's Age, Sustainable Entrepreneurial Orientation and Sustainable Performance: A Conceptual Outlook. Sustainability, 12(8), 3196. https://doi.org/10.3390/su12083196

Artar, M. (2019). Generation Y' and Narcissism Conference: ISMC 2019 - 15th International Strategic Management Conference. https://doi.org/10.15405/epsbs.2019.10.02.24

Ballestar, M. T., Díaz-Chao, Á., Sainz, J. \& Torrent-Sellens, J. (2020). Knowledge, robots and productivity in SMEs: Explaining the second digital wave. Journal of Business Research, 108(1), 119-131. https://doi.org/10.1016/j.jbusres.2019.11.017

Bednáriková, M. (20013). Úvod do metodológie vied (Introduction to the methodology of sciences). Trnava: Filozofická fakulta Trnavskej univerzity v Trnave.

Bilan, Y., Hafezali I. H., Muhammad H. \& Sebastian K. (2020). Sustainability and Economic Performance: Role of Organizational Learning and Innovation. Inzinerine Ekonomika-Engineering Economics, 31(1), 93-103. https://doi.org/10.5755/j01.ee.31.1.24045

Blahová, J. \& Pauliková, A. (2019). Psychosocial work strain and its influence on decision-making processes. ICERI 2019 Proceedings 12th International Conference of Education. Research and Innovation. 3898-3905. https://doi.org/10.21125/iceri.2019.0986

Browne, J., Devlin, J., Rolstadas, A. \& Andersen, B. (1997). Performance measurement: The ENAPS approach. The International Journal of Business Transformation. Available from internet: https://www.researchgate.net/publication/233862752_Performance_measurement_The_ENAPS_approach

Bruni, D. S. \& Verona, G. (2009). Dynamic marketing capabilities in Science-based firms: An exploratory investigation of the pharmaceutical industry. British Journal of Management, 20(1), 101-117. https://doi.org/10.1111/j.1467-8551.2008.00615.x

Čambál, M., Cagáňová, D. \& Šujanová, J. (2012). The industrial enterprise performance increase through the competency model application. Proceedings of the 4th European Conferences on Intellectual Capital (ECIC 2012), 108-126.

Češčut, R. (2010). Generation X in Slovenia(n). Acta Neophilologica, 43(1-2), 93-105. https://doi.org/10.4312/an.43.1-2.93-105

Chardine-Baumann, E. \& Botta-Genoulaz, V. (2014). A framework for sustainable performance assessment of supply chain management practices. Computers \& Industrial Engineering, 76(2014), 138-147. https://doi.org/10.1016/j.cie.2014.07.029

Coleman, L., Hladikova, M. \& Savelyeva, M. (2006). The baby boomer market. J Target Meas Anal Mark, 14, $191-209$. https://doi.org/10.1057/palgrave.jt.5740181

Cortina, J. M. (1993). What is coefficient alpha? An examination of theory and applications. Journal of Applied Psychology, 78(1), 98104. https://doi.org/10.1037/0021-9010.78.1.98

Dancu, V. S. (2015). Generation X - Romania's fallen generation. Available from internet: https://www.researchgate.net/publication/314351685_Generation_X 


\section{ENTREPRENEURSHIP AND SUSTAINABILITY ISSUES}

ISSN 2345-0282 (online) http://jssidoi.org/jesi/ 2021 Volume 9 Number 2 (December)

http://doi.org/10.9770/jesi.2021.9.2(23)

Davcik N.S., Sharma P. \& Grigoriou N. (2017). Exploring the Role of Brand Equity and R\&D as Drivers of Product Innovation and Market Performance. In: Rossi P. (eds) Marketing at the Confluence between Entertainment and Analytics. Developments in Marketing Science: Proceedings of the Academy of Marketing Science. Springer, Cham. Deal, J. J. (2007). Retiring the Generation Gap How Employees Young and Old Can Find Common Ground. San Francisco: Jossey-Bass, Wiley \& Sons. https://doi.org/10.1007/978-3-319-47331-4_3

Deal, J. J. (2007). Retiring the Generation Gap How Employees Young and Old Can Find Common Ground. San Francisco: Jossey-Bass, Wiley \& Sons.

Debnár, R. (2020). Ste pripravení zvládnut' krízu bez výraznejších následkov? (Are you ready to handle the crisis without significant consequences?) Available from internet: https://www.ipaslovakia.sk/clanok/ste-pripraveni-zvladnut-krizu-bez-vyraznejsichnasledkov?utm_source=IPA+Slovakia+web\&utm_campaign $=65$ bbbe $162 \mathrm{c}-$

20200424_koucing\&utm_medium=email\&utm_term=0_b0cc9f06ca-65bbbe162c-

$236628413 \& \mathrm{ct}=\mathrm{t}(20200424$ koucing $) \& \mathrm{mc}$ cid $=65 \mathrm{bbbe} 162 \mathrm{c} \& \mathrm{mc}$ eid $=2 \mathrm{~d} 87474 \mathrm{~d} 5 \mathrm{e}$

Delaney, T. J. \& Huselid, M. A. (1996). The Impact of Human Resource Practices on Perceptions Organizational Performance. The Academy of Management Journal, 39(4), 949-969. https://doi.org/10.5465/256718

Dollinger, M. J., \& Golden, P. A. (1992). Interorganizational and collective strategies in small firms: Environmental effects and performance. Journal of Management, 18(4), 695-715. https://doi.org/10.1177/014920639201800406

EFQM Excellence Model. (2003). Brussels: EFQM.

El-Gohary, H. \& Eid, R. (2013). Leadership teaching impact on tourism students' attitudes and perceptions toward leadership in developing economies: The case of Egypt. Journal of Hospitality \& Education, 25(4), 180-192. https://doi.org/10.1080/10963758.2013.850297

Euler H. (2020). TLAČOVÁ SPRÁVA. Kríze Covid-19 neunikne takmer žiadne odvetvie. Ktoré tri odvetvia sú zasiahnuté najviac? (PRESS RELEASE. The Covid-19 crisis will escape almost no industry. Which three sectors are most affected?) Available from internet: www.eulerhermes.sk

Falciola, J., Jansen, M. \& Rollo, V. (2020). Defining firm competitiveness: A multidimensional framework. World Development, 129(2020), 104857. https://doi.org/10.1016/j.worlddev.2019.104857

Feeney, P. (2015). The Baby Boomer Generation: A Lifetime of Memoriesm. United Kingdom. The History Press.

Fibírová, J. \& Šoljaková, L. (2005). Hodnotové nástroje řízení a měření výkonnosti podniku (Value tools for managing and measuring business performance). Praha: ASPI.

Gavurova, B., Kocisova, K., Behun, M. \& Tarhanicova, M. (2018). Environmental performance in OECD countries: A non-radial DEA approach. Acta Montanistica Slovaca, 23(2), 206-215.

Gejdoš, P. \& Rentková K. (2019). Benefits of process management and their impact on performance improvement in the Slovak business environment. Proceedings of the international conference on Economics, management and technology in enterprises, 78(1), 53-56.

Goh, E. \& Jie, F. (2019). To waste or not to waste: Exploring motivational factors of Generation Z hospitality employees towards food wastage in the hospitality industry. International Journal of Hospitality Management, 80(1), 126-135. https://doi.org/10.1016/j.ijhm.2019.02.005

Gravett, L., Throckmorton, R. (2007). Bridging the Generation Gap. How to Get Radio Babies, Boomers, Gen Xers, and Gen Yers to Work Together and Achieve More. USA, Franklin Lakes. Career Press.

Grenčíková, A., Španková, J. (2016). Labour Migration Trends in the Slovak Republic. Journal of Scientific Papers ECONOMICS \& SOCIOLOGY, 9(2), 158-167. https://doi.org/10.14254/2071-789X.2016/9-2/11

Grifell-Tatjé, E. \& Lovell, C. (1999). Profits and Productivity. Management Science, 45(9), 1177-1193. Available from internet: https://www.jstor.org/stable/2634831

Gyurák Babel'ová, Z., Stareček, A., Koltnerová, K. \& Cagáňová, D. (2020). Perceived Organizational Performance in Recruiting and Retaining Employees with Respect to Different Generational Groups of Employees and Sustainable Human Resource Management. Sustainability, 12(2), 574. https://doi.org/10.3390/su12020574 


\section{ENTREPRENEURSHIP AND SUSTAINABILITY ISSUES}

ISSN 2345-0282 (online) http://jssidoi.org/jesi/

2021 Volume 9 Number 2 (December)

http://doi.org/10.9770/jesi.2021.9.2(23)

He, Q., Guaita-Martínez, J. M. \& Botella-Carrubi, D. (2019). How brand equity affects firm productivity: The role of R\&D and human capital. Economic Research-Ekonomska Istraživanja. 1-17. https://doi.org/10.1080/1331677X.2019.1686045

Huselid, M. A. (1995). The Impact of Human Resource Management Practices on Turnover, Productivity, and Corporate Financial Performance. Academy of Management Journal, 38(3), 635-672.

Hussain, I., Mu, S., Mohiuddin, M., Danish, R.Q. \& Sair, S.A. (2020). Effects of Sustainable Brand Equity and Marketing Innovation on Market Performance in Hospitality Industry: Mediating Effects of Sustainable Competitive Advantage. Sustainability, 12(7), 2939. https://doi.org/10.3390/su12072939

Hysa, B. (2016). Zarządzanie różnorodnością pokoleniową (Establishment of generational generations). Zeszyty. Naukowe Politechniki Śląskiej, seria Organizacjai Zarządzanie, 97(1964), 385-398.

Indriyana, F. \& Djastuti, I. (2019). Work values of generation Y. Diponegoro International Journal of Business, 1(1), 40-48. https://doi.org/10.14710/dijb.1.1.2018.40-48

Ishaq B. M., Awan, H.M. \& Razaq, Z. (2014). The key performance indicators (KPIs) and their impact on overall organizational performance. Qual Quant, 48, 3127-3143. https://doi.org/10.1007/s11135-013-9945-y

Janišová D. \& Křivánek M. (2013). Velká kniha o řízení firmy. Praktické postupy pro úspěšný rozvoj (A great book on business management. Practical procedures for successful development). Praha: Grada Publishing.

Jurík, L., Horňaková, N., Šantavá, E., Cagaňaová, D. \& Sablik, J. (2020). Application of AHP method for project selection in the context of sustainable development. Wireless Networks, 1-10. https://doi.org/10.1007/s11276-020-02322-2

Kamenidou, I. C., Mamalis, S. A., Pavlidis, S. \& Bara, E. Z. G. (2019). Segmenting the Generation Z Cohort University Students Based on Sustainable Food Consumption Behaviour: A Preliminary Study. Sustainability, 11(3), 837. https://doi.org/10.3390/su11030837

Karasek, A. \& Hysa, B. (2020). Social media and generation Y, Z - A challenge for employers. Scientific Papers of Silesian University of Technology - Organization and Management Series, 144, 227-237. http://dx.doi.org/10.29119/1641-3466.2020.144.18

Karlöf, B. \& Lövingsson F. H. (2006). Management od A do Z. Klíčové pojmy a termíny (Management from A to Z. Key terms and terms). Brno: Computer Press.

Katz, H. C., Kochan, T. A. \& Keefe, J. H. (1987). Industrial Relations and Productivity in the U.S. Automobile Industry. Brookings Papers on Economic Activity, 18(3), 685-728. http://dx.doi.org/10.2307/2534452

Katz, S. (2017). Generation X: A Critical Sociological Perspective. Journal of the American Society on Aging, 41(3), 12-19.

Kaylene, C. W., Robert, A. P., Alfred, R. P. \& Edward, H. H. (2010). Multi- Generational Marketing: Descriptions, Characteristics, Lifestyles, and Attitudes. Journal of Applied Business and Economics, 11(2), 1-17.

Kohnová, L., Papula, J. \& Salajová, N. (2019). Internal factors supporting business and technological transformation in the context of Industry 4.0. Business: Theory and Practice, 20, 137-145. https://doi.org/10.3846/btp.2019.13

Košturiak J. \& Chal'. J. (2008). Inovace: Vaše konkurenční výhoda! Brno: Computer Press.

Kuchárová-Mačkayová, V. \& Balážová, V. (2011). Characteristics of generation Y and its future occupation - comparison of opinions. HRM\&E. 5(1), 78-93.

Kupperschmidt, B. R. (2000). Multigeneration Employees: Strategies for Effective Management. The Health Care Manager Journal, (19(1), 65-76.

Kutlák, J. (2019). Generations $\mathrm{Y}$ and $\mathrm{Z}$ in the workplace: perception of teamwork. ACC JOURNAL, 25(2), 65-77. https://doi.org/10.15240/tul/004/2019-2-005

Lesáková, L. (2004). Metódy hodnotenia výkonnosti malých a stredných podnikov (Methods for evaluating the performance of small and medium - sized enterprises). Banská Bystrica: Univerzita Mateja Bela, Ekonomická fakulta. 


\section{ENTREPRENEURSHIP AND SUSTAINABILITY ISSUES}

ISSN 2345-0282 (online) http://jssidoi.org/jesi/

2021 Volume 9 Number 2 (December)

http://doi.org/10.9770/jesi.2021.9.2(23)

Lorincová, S., Štarchoň, P., Weberová, D., Hitka, M. \& Lipoldová, M. (2019). Employee Motivation as a Tool to Achieve Sustainability of Business Processes. Sustainability, 11(13), 3509. https://doi.org/10.3390/su11133509

Majdúchová, H. \& Rybárová, D. (2019). Podnikové hospodárstvo pre manažérov (Business Economy for managers). Bratislava: Wolters Kluwer.

Marin-Garcia, J. A., Miralles, C., Garcia-Sabater, J. P. \& Perello-Marin, M. R. (2011). Alternative tools to mass production and human performance indicators in sheltered work centers of Valencian community (Spain). Journal of Industrial Engineering and Management, 4(3), 467-480. http://dx.doi.org/10.3926/jiem.2011.v4n3.p467-480

Marr, B. (2006). Strategic Performance Management. Leveraging and measuring your intangible value drivers. First edition. Oxford: Elsevier.

Matraeva, L., Vasiutina, E., Belyak, A, Solodukha, P., Bondarchuk, N. \& Efimova. M. (2019). Economic Model of Generation Z Behavior. Academic Journal of Interdisciplinary Studies, 8(3), 123-324. https://doi.org/10.36941/ajis-2019-0011

May, G. \& Stahl, B. (2017). The significance of organizational change management for sustainable competitiveness in manufacturing: exploring the firm archetypes, International Journal of Production Research, 55(15), 4450-4465. https://doi.org/10.1080/00207543.2016.1261197

Mayhand, D. (2020). Globalization: Understanding the Impact of Cultural Differences in Global Organizations. Open Journal of Leadership, 9(1), 34-52. https://doi.org/10.4236/oj1.2020.91003

McCrindle, M. \& Wolfinger, E. (2011). The ABC of XYZ. Understanding the Global Generations. Sydney: University of New South Wales Press.

Míkva, M., Vaňová, J. \& Szabó, P. (2017). Evaluation of employees' performance - identification of problems and proposals for their elimination. Journal of Interdisciplinary Research, 7(2), 219-224.

Mosca, J., Curtis, K. P. \& Savoth, G. P. (2019). New Approaches to Learning for Generation Z. Journal of Business Diversity, 19(3), 6674. https://doi.org/10.33423/jbd.v19i3.2214

Murphy, E. F., Gibson, J. W. \& Greenwood, R. A. (2010). Analyzing Generational Values among Managers and Non-Managers for Sustainable Organizational Effectiveness. SAM Advance Management Journal, 75(1), 2010, 33-55.

Neal, S. \& Wellins, R. (2018). Generation X - not millennials - is changing the nature of work. Available from internet: https://www.cnbc.com/2018/04/11/generation-X--not-millennials--is-changing-the-nature-of-work.html

Neumaierová, I. \& Neumaier, I. /2019). Výkonnost a tržní hodnota firmy (Performance and market value of the company). Praha: Grada.

Ochrana, F. 2019. Metodologie, metodya metodikavědeckého výzkumu (Methodology, methods and methods of scientific research). Praha: Nakladatel'stvo Karolinum.

Oczachowska, A. (2020). Purchase Behaviours of Generation Y. Annales Universitatis Mariae Curie-Skłodowska sectio H Oeconomia, 54(1), 67-75. https://doi.org/10.17951/h.2020.54.1.67-75

Powell, T. C. (1992). Organizational alignment as competitive advantage. Strategic Management Journal, 13(2). 119-134. https://doi.org/10.1002/smj.4250130204

Rolstadås, A. (1998). Enterprise performance measurement. International Journal of Operations \& Production Management, 18(9/10), 989999. https://doi.org/10.1108/01443579810225577

Rr, E. (2020). The effects of leadership and employee performance on innovation performance among Indonesian SMES. Polish Journal of Management Studies, 21(2), 370-383. https://doi.org/10.17512/pjms.2020.21.2.26

Samáková, J., Babčanová, D., Hrablik Chovanová, H., Mesárošová, J. \& Šujanová, J. (2017). Using the communication methods, tools and support during management of project communication in industrial manufacturing enterprises. Vedecké práce MtF STU v Bratislave so sídlom v Trnave. Research papers Faculty of Materials Science and Technology Slovak University of Technology in Trnava, 25(41), 51-62. https://doi.org/10.1515/rput-2017-0021 


\section{ENTREPRENEURSHIP AND SUSTAINABILITY ISSUES}

ISSN 2345-0282 (online) http://jssidoi.org/jesi/ 2021 Volume 9 Number 2 (December)

http://doi.org/10.9770/jesi.2021.9.2(23)

Sayers, R. (2007). The Right Staff from X to Y. Library Management, 28(8/9), 474-487. https://doi.org/10.1108/01435120710837765

Schaltegger, S., Wagner, M. (2017). Managing the Business Case for Sustainability. The Integration of Social, Environmental and Economic Performance. London: Routledge. Available from internet: https://www.routledge.com/Managing-the-Business-Case-forSustainability-The-Integration-of-Social/Schaltegger-Wagner/p/book/9781874719953

Shah, U. A. \& Khan, I. M. (2019). HRM-Performance Perspectives: An Overview of Theoretical Challenges and Prospects. Inzinerine Ekonomika-Engineering Economics, 30(3), 382-393. https://doi.org/10.5755/j01.ee.30.3.9550

Spiro, C. (2006). Generation $\mathrm{Y}$ in the Workplace. Defense AT\&L. Available from internet: http://washingtonandco.com/pdf/generation_y_workplace.pdf

Spišáková, A., Vraňaková, N., Koltnerová, K. \& Chlpeková, A. (2016). Design of the implementation of concept of age management in industrial companies. Fórum manažéra, 12(2), 52-56.

Stacho, Z., Stachová K., Papula J., Papulová Z. and Kohnová L. (2019). Effective communication in organizations increases their competitiveness. Polish Journal of Management Studies. 19(1), 391-403. https://doi.org/10.17512/pjms.2019.19.1.30

Stachová, K., Stacho, Z., Cagáňová, D. \& Stareček, A. (2020). Use of Digital Technologies for Intensifying Knowledge Sharing. Applied Sciences, 10(12), 4281. https://doi.org/10.3390/app10124281

Stýblo, J. (2008). Výkonnost' firiem (Company performance). Moderní rízení, 43(11), 1-25.

Sudbury-Riley, L., Kohlbacher, F. \& Hofmeister, A. (2015). Baby Boomers of different nations: Identifying horizontal international segments based on self-perceived age. International Marketing Review, 32(3/4), 245-278. https://doi.org/10.1108/IMR-09-2013-0221

Šulák, M. \& Vacík, E. (2005). Měření výkonnosti podniku (Measuring business performance). Praha: Vysoká škola finanční a správní.

Sullivan, A., Brown, M. \& Bann, D. (2015). Generation X enters middle age. Longitudinal and Life Course Studies, 6(2), 120-130. http://dx.doi.org/10.14301/1lcs.v6i2.351

Suryani, A., Pirzada, K. \& Mufidah, M. (2018). Analysis of opportunistic behavior of management to company performance. Polish Journal of Management Studies. 18(1), 379-388. https://doi.org/10.17512/pjms.2018.18.1.28

Székely, F. \& Knirsch, M. (2005). Responsible Leadership and Corporate Social Responsibility: Metrics for Sustainable Performance. European Management Journal, 23(6), 628-647. https://doi.org/10.1016/i.emj.2005.10.009

Tomčíková M. (2011). Výkonnost'-faktor úspešnosti organizácie (Performance - a factor in the success of an organization). Available from internet: https://www.konference.fbm.vutbr.cz/workshop/papers/papers2011/ekonomika/Tomcikova.pdf

Topolosky, P. S. (2000). Linking Employee Satisfaction to Business Results. Routledge, Garland Publishing.

United Nations (2020). World Population Prospects 2019. Available from internet: http://esa.un.org/wpp/Sorting-Tables/tabsorting_ageing.htm

Veber, J. (2001). Management. Základy, prosperita, globalizace (Management. Basics, prosperity, globalization). Praha: Management Press.

Wagner, J. (2009). Měření výkonnosti. Jak měřit, vyhodnocovat a využívat informace o podnikové výkonnosti (Performance measurement. How to measure, evaluate and use information about business performance). Praha: Grada Publishing.

Závadská, Z. \& Závadský, J. (2014). Integrácia procesného manažmentu do systému riadenia podniku (Integration of process management into the business management system). Bratislava: Slovenský komitét pre vedecké riadenie ZSVTS. 


\section{ENTREPRENEURSHIP AND SUSTAINABILITY ISSUES}

ISSN 2345-0282 (online) http://jssidoi.org/jesi/

2021 Volume 9 Number 2 (December)

http://doi.org/10.9770/jesi.2021.9.2(23)

\section{Acknowledgments}

The paper is a part of project VEGA No. 1/0721/20 „Identification of priorities for sustainable human resources management with respect to disadvantaged employees in the context of Industry 4.0 "

Zdenka GYURÁK BABELOVÁ (corresponding author) is a senior lecturer and researcher at the Institute of Industrial Engineering and Management, Faculty of Materials Science and Technology in Trnava, Slovak University of Technology in Slovakia. Her field of research is performance management, human resource management, work organization, work conditions, ergonomics, staff development, education, training, investments into human resources, enterprises management systems effectiveness, growth and sustainability of enterprise performance. Currently, she works on projects focused on human resource management and company management improvement, age management, and the impact of Industry 4.0 on human resource management.

ORCID: https://orcid.org/0000-0002-9927-3812

Augustín STAREČEK is a researcher at the Institute of Industrial Engineering and Management at the Faculty of Materials Science and Technology in Trnava. His area of expertise is human resource management with a focus on employee motivation and sustainable performance management, and he focuses on process optimization in the field of logistics and production. The dominant areas of his pedagogical scope are the subjects: Operational Analysis, Information and Knowledge Management, and Managerial Skills.

ORCID: https://orcid.org/0000-0003-3652-8969

Make your research more visible, join the Twitter account of ENTREPRENEURSHIP AND SUSTAINABILITY ISSUES: @Entrepr69728810

Copyright (C) 2021 by author(s) and VsI Entrepreneurship and Sustainability Center

This work is licensed under the Creative Commons Attribution International License (CC BY).

http://creativecommons.org/licenses/by/4.0/

(c) (i) Open Access 